\title{
SELECTED ISSUES OF THE DEVELOPMENT OF SMALL MUNICIPALITIES IN THE CZECH REPUBLIC, FINANCING OF MUNICIPALITIES
}

\author{
Jaroslava Kadeřábková ${ }^{1}$, Marek Jetmar ${ }^{2}$
}

Received 19 November 2009; Accepted 17 September 2010

\begin{abstract}
Decentralization of decision-making on the availability of essential public goods for regional and local level raises questions regardless of ability to ensure or guarantee the supply by the small municipalities. It affects the delicate problem of fiscal decentralization and own limits of decentralization process. In this paper, we deal with problems concerning primarily the development of small municipalities as independent public corporations, their ability to play the self-government role and to ensure the availability of essential public goods and services. The main criteria for defining small rural communities are the population and the status of municipality in the settlement structure, which is a predetermined by range of services provided at territory of municipality (market services, public services) to its citizens and residents of surrounding villages. We deal with problems of financing small communities, their participation in the distribution of revenue from shared taxes, the availability of other resources. We monitor the factors that enter into models of reallocation of public resources. We base their findings mot only on information from literature, but also from terrain research, which not only confirmed some previously published facts, but allowed to reveal the factors that significantly affect the financial situation of small municipalities. This led to the determination of parameters, the key mechanism for setting the allocation of public resources. On the basis of the investigation, we analyze the parameters, the key mechanism for setting the allocation of public resources. In conclusion, the authors summarize the main issues and articulate the principles that should be respected in the formulation and adjustment of the budget determination.
\end{abstract}

Key Words: rural areas, communities, funding to municipalities, tax revenue, delegated power

Abstrakt: Decentralizace rozhodovaciho procesu týkající se dostupnosti základních veřejných statků na místní a regionální úrovni vyvolává otázky ohledně schopnosti jejich zajištění (případně garantování jejich poskytování) ze strany malých obcí. Je úzce spojena s citlivým problémem fiskální decentralizace i vlastními limity procesu

\footnotetext{
1 PhDr. Jaroslava Kadeřábková, CSc., Department of Regional Studies, University of Economics in Prague, W. Churchilla 4, 13069 Prague 3, e-mail: kaderi@vse.cz

${ }^{2}$ Ing. Marek Jetmar, Ph.D., Department of Regional Studies, University of Economics in Prague, W. Churchilla 4, 130 69 Prague 3, e-mail: jetmar@vse.cz
} 
decentralizace. $V$ našem příspěvku se zabýváme problémy týkající se především rozvoje malých obcí jako nezávislých veřejnoprávních korporací, jejich schopnost plnit samosprávnou roli při zajištění dostupnosti základních veřejných statků a služeb. Hlavní kritéria pro definování malých venkovských obcí jsou počet obyvatel a postavení obce $\mathrm{v}$ sídelní struktury, které je determinováno rozsahem služeb poskytovaných na území obce (tržní služby, veřejné služby) svým občanům a obyvatelům okolních obcí. Zabýváme se problematikou financování malých obcí, jejich participací na rozdělování výnosu sdílených daní, dostupností dalších zdrojů. Sledujeme faktory, které vstupují do modelů přerozdělování veřejných zdrojů. Své poznatky opíráme nejen o informace z odborné literatury, ale i z terénního šetření, které nejen potvrdilo některé již dřív publikované skutečnosti, ale umožnilo odhalit i faktory, které významným způsobem ovlivňují finanční situaci malých obcí. $\mathrm{Na}$ základě provedených šetření analyzujeme parametry, klíčové pro nastavení mechanismu přerozdělování veřejných zdrojů. V závěru příspěvku shrnujeme hlavní problémy a formulujeme principy, které by se měly respektovat při stanovování a úpravách rozpočtového určení daní.

Klíčová slova: venkov, obce, finacování obcí, rozpočtové určení daní, přenesená působnost

\section{Introduction}

The existence of small municipalities, their ability to ensure effectively the availability of at least the essential public goods and services for local population is currently a focus of attention of both professional and interested public (Andrle 1998). This public interest has resulted, inter alia, in the commissioning and elaboration of a project focusing mainly on an examination of sources designated for funding of local public goods. The examination of issues concerning small municipalities needs a comprehensive approach, which requires an analysis of the material content of activities carried on by territorial self-government authorities, including the general legislative framework for provision of public goods and services, particularly under independent competencies. This objective approach should be supplemented with an analysis of possibilities of funding the operation of the municipality and provision of public services.

Socio-geographic perspective is one of the major approaches, but not always clarifies the points to the possibility of developing and maintenance of small municipalities. Socio-cultural aspects and historical geographical analysis of the development of small communities also contributes to understanding the functioning of local trends. These approaches, however, does not address the real possibility of maintaining and developing these sites, since they contain economics (particularly financial and property aspects), which are an important factor influencing the range and quantity of public goods and services which the municipality can provide, and which directly and indirectly affect the quality of life of rural communities.

Our paper is based on a presumption that, under the existing conditions, small municipalities are unable to ensure the range of goods and services that are commonly required by their citizens (the availability and quality of the technical and social infrastructure). To capture these problems, we will use, among others, the results of a large-scale research carried out by the Department of Regional Studies, University of Economics in Prague, as a part of the research project "Analysis of funding of the execution of state administration and self-administration by territorial self-government units", an interdisciplinary approach, which contributed to the identification and examination of links among the social, administrative, economic and spatial (including geographic) roles of municipalities and the impact of these roles on their funding. Both quantitative and qualitative examination methods were used in the research. Results of statistical analyses were verified by an electronic questionnaire survey on a selected representative sample of municipalities in the Czech Republic.

\footnotetext{
${ }^{3}$ The contracting party was the Ministry of Finance of the Czech Republic; the survey was carried out in 2008-2009; the quantitative analysis used the latest available data, i.e. income and expenditure of municipalities in 2005-2007, were used in.
} 
The sample took into account the size category of the municipalities, as well as their prevailing functional role (including their administrative role, i.e. their activities performed under their independent and delegated powers), and their geographic location. A special attention was paid to small municipalities, where the previous statistical and empiric surveys had been unable to capture the essence of the problem.

When selecting a representative samples of villages were monitored the following parameters: size of residence, geographic location (Czech and Moravian regions, border areas), socioeconomic role, position in the settlement structure, the administrative role.

\begin{tabular}{|l|c|c|c|c|}
\hline \multicolumn{1}{|c|}{ Regions } & $\begin{array}{c}\text { Municipalities with } \\
\text { extended power } \\
\text { (ORP) }\end{array}$ & $\begin{array}{c}\text { Municipalities with } \\
\text { authorized } \\
\text { municipal authority }\end{array}$ & $\begin{array}{c}\text { Other municipalities } \\
\text { (all subcategories of } \\
\text { small municipalities). }\end{array}$ & Total \\
\hline Jihočeský kraj & 17 & 10 & 11 & $\mathbf{3 8}$ \\
\hline Jihomoravský kraj & 21 & 8 & 18 & $\mathbf{4 7}$ \\
\hline Karlovarský kraj & 7 & 4 & 15 & $\mathbf{1 5}$ \\
\hline Kraj Vysočina & 15 & 10 & 8 & $\mathbf{4 0}$ \\
\hline $\begin{array}{l}\text { Královéhradecký } \\
\text { kraj }\end{array}$ & 15 & 10 & 9 & $\mathbf{3 3}$ \\
\hline Liberecký kraj & 10 & 6 & 5 & $\mathbf{2 5}$ \\
\hline $\begin{array}{l}\text { Moravskoslezský } \\
\text { kraj }\end{array}$ & 22 & 4 & 21 & $\mathbf{3 1}$ \\
\hline Olomoucký kraj & 13 & 8 & 19 & $\mathbf{4 4}$ \\
\hline Pardubický kraj & 15 & 12 & 25 & $\mathbf{4 6}$ \\
\hline Plzeňský kraj & 15 & 16 & 7 & $\mathbf{6 7}$ \\
\hline Středočeský kraj & 26 & 7 & 11 & $\mathbf{2 9}$ \\
\hline Ústecký kraj & 16 & 5 & & 7 \\
\hline Zlínský kraj & 13 & 4 & & \\
\hline
\end{tabular}

Tab 1. Number of municipalities that were included in the empirical investigation

Source: Prepared on the basis of data provided by research team

Small municipalities usually lacked sufficient capacity to participate in a questionnaire survey. On the one hand, managed interviews showed a plasticity of opinions; on the other hand, they accentuated the necessity to take into account specific features of small municipalities, both with regard to funding and with regard to the provision of necessary public services, as well as the limits of their ability to assume further tasks from the state.

Results have shown mutual links among social, administrative, economic and spatial functions of the municipalities (position in the rural settlement pattern, involvement in economic relations) and their impact on economy of municipalities and their funding. Taking into account all these dimensions can contribute to the discussion about the role of small municipalities in the process of distribution local public goods and services and the method of their financing.

\section{Municipalities and decentralization process}

The decentralization and reform of public administration resulted in the delegation of a number of tasks and competencies to municipalities. Therefore, even small municipalities fulfil tasks under independent and delegated competencies (Matula - Kuba 2007). The public administration reform was followed by a change in the funding system of municipalities (Blažek 2003). Principles applied in the distribution of funds to municipalities were supposed to ensure stabilization of municipal budgets and a balanced dynamic of the entire public budget system. This process was a reaction to the development in a number of Western countries. The set-up of public budgets and funding of municipalities have undergone a number of adjustments; 
despite these modifications, further suggestions for their adjustment are being submitted, mostly by small municipalities.

Revival the self-governing status of municipalities also meant the release of the decisionmaking rules in the procurement and asset management. Municipalities received from the state historic assets, property of the local national committees and other assets in the privatization process and transform state-owned organizations.

Decision-making on municipal property is for more than 20 years entirely in the hands of the political representation of local government. It depends on the preferences of elected representatives how to use municipal property and their ability to deal with it effectively and efficiently, ie to the benefit of the municipality and its citizens.

\section{Characteristics of the settlement structure of the Czech Republic}

The current settlement structure in the Czech Republic and the form of settlements is a result of many years of the development of our territory, which reflected to a different scope the economic, social and political impacts. The transformation of rural settlements and its impact is also a reflection of historic development associated with social and economic changes including also urbanization processes. The consequence of these processes is characterized by a residential structure of the Czech lands, but the specific impacts of urbanization in some parts of Bohemia and Moravia, in the border regions (eg. resulting from differences in the size structure of holdings, treatment to property, his inheritance, etc.). These issues have been and are still the focus of attention of many Czech and foreign authors and institutions (see e.g. Andrle 2003, Andrle - Hladík 2002, Hampl 1999, Hampl 2005, Hampl 1996, Hampl - Gardavský - Kühnl 1987, Hampl - Müller 1998, Koledová 1997, Matoušek 1991).

Our territory is characterized by a high population density and the prevailing number of small settlements. About $40.5 \%$ of the population of the state lives in the rural space. Settlements with the population between 100 and 1,500 inhabitants prevail in some regions of the Czech Republic ${ }^{4}$. A typical feature of other parts of the country are small settlements with the population between 30 and 100 dwellings, as well as a relatively dense network of small municipalities and smaller towns up to 10,000 of inhabitants.

Despite the long-term stability of the number of settlements (leaving aside non-recurrent impacts, such as the incomplete settlement of border regions), the number of municipalities was changing in the past. Economic reasons based on the historical political development resulted in changes of the administrative structure, either to administrative merging or to the opposite process of division of municipalities (Kadeřábková 2008). This development is reflected in the existence of parts of municipalities, which were formerly territorially separated settlements. The persisting territorial separation of settlements is typical primarily for rural and semirural municipalities. More than 15,000 of them are registered in the Czech Republic and some 11,500 parts of municipalities are situated in the countryside. In the European context, the Czech Republic belongs together with France to countries with the highest number of small municipalities (the average number of inhabitants per one municipality amounted as of 1 January 2007 to 1,646$)$.

\footnotetext{
${ }^{4}$ Rural municipalities have not yet been clearly defined in the Czech Republic. The most frequently used definitions of rural municipalities may be generally divided, by their content, in accordance with four key criteria:

- definitions based on the status of the settlement;

- definitions based on population density;

- definitions based on the size of the municipality;

- definitions based on other characteristics of the municipality.

The generally recognized definition formulated by the Organization for Economic Cooperation and Development (OECD), which is based on the share of the population living in a territory with a population density lower than 150 inhabitants $/ \mathrm{km}^{2}$ of the total number of inhabitants, cannot be fully accepted in the conditions of the Czech Republic, as regards funding of the development and renewal of rural municipalities, e.g. in the Rural Development Programme of the Czech Republic for 2007-2013, which uses the size of the municipality, i.e. municipalities up to 500 inhabitants, or municipalities up to 2,000 inhabitants, as the criterion for renewal and development of the rural areas.
} 


\begin{tabular}{|l|r|r|r|r|}
\hline $\begin{array}{l}\text { Size category of municipalities } \\
\text { defined by the Ministry of Finance } \\
\text { of the Czech Republic (in 2007) }\end{array}$ & $\begin{array}{l}\text { Number of } \\
\text { municipalities } \\
\text { in the category }\end{array}$ & \multicolumn{4}{|c|}{$\begin{array}{c}\text { Number of } \\
\text { inhabitants as of } \\
\text { 1 January 2007 }\end{array}$} & \multicolumn{1}{c|}{$\%$} \\
\hline Up to 100 inhabitants & 539 & $8.63 \%$ & 38,388 & $0.37 \%$ \\
\hline $101-200$ inhabitants & 1067 & $17.09 \%$ & 159,533 & $1.55 \%$ \\
\hline $201-300$ inhabitants & 878 & $14.06 \%$ & 215,321 & $2.09 \%$ \\
\hline $301-1500$ inhabitants & 2888 & $46.25 \%$ & $1,910,686$ & $18.58 \%$ \\
\hline $1,501-5,000$ inhabitants & 600 & $9.61 \%$ & $1,524,149$ & $14.82 \%$ \\
\hline $5,001-10,000$ inhabitants & 140 & $2.24 \%$ & 947,225 & $9.21 \%$ \\
\hline $10,001-20,000$ inhabitants & 69 & $1,11 \%$ & 962,930 & $9.36 \%$ \\
\hline $20,001-30,000$ inhabitants & 27 & $0.43 \%$ & 663,049 & $6.45 \%$ \\
\hline $30,001-40,000$ inhabitants & 10 & $0.16 \%$ & 348,408 & $3.39 \%$ \\
\hline $40,001-50,000$ inhabitants & 5 & $0.08 \%$ & 231,332 & $2.25 \%$ \\
\hline $50,001-100,000$ inhabitants & 16 & $0.26 \%$ & $1,156,650$ & $11.25 \%$ \\
\hline $100,001-150,000$ inhabitants & 1 & $0.02 \%$ & 100,168 & $0.97 \%$ \\
\hline 150,001 inhabitants and over & 3 & $0.05 \%$ & 839,170 & $8.16 \%$ \\
\hline Capital City of Prague & 1 & $0.02 \%$ & $1,188,126$ & $11.55 \%$ \\
\hline Total & $\mathbf{6 , 2 4 4}$ & & $\mathbf{1 0 , 2 8 5 , 1 3 5}$ & \\
\hline
\end{tabular}

Tab 2. Classification of municipalities by size used for funding purpose ${ }^{5}$

Source: Prepared on the basis of data provided by the Ministry of Finance of the Czech Republic

This settlement nature creates specific conditions for agricultural production and other economic activities, for commuting to work and services, for the way of life and culture of the population ${ }^{6}$.

Recent years have witnessed deepening of differences between the development of rural areas in geographically remote regions and rural regions near big cities with attractive surroundings or with stabilized (presently also multifunctional) agricultural sector (Perlín - Kuldová 2008). The problem of destabilization currently concerns mainly peripheral rural regions. On the contrary, rural municipalities situated near big cities in the Czech Republic have witnessed a population increase in the last decades ${ }^{7}$.

The process of depopulation of the countryside is slowed down by the increasing living standard of the population not only in cities, but also in the countryside, which was facilitated by the development of individual automobile transport, by the appreciation of the quality of the rural environment, the preference of living in family homes, etc. On the other hand, there are also opposite processes. Another phenomenon that is currently added to the above factors is uncontrolled suburbanization, which appears mainly in the vicinity of big cities and which often degrades the advantages of life in the countryside (Baše - Cílek 2006).

These characteristics affect significantly the development potential of the relevant territories. The size of municipalities as territorial units with a specific number of inhabitants is one of the factors that may affect the efficiency of municipalities (on one side ensure the normal operation of the village, on other side promote the effect of agglomeration economies) and effectiveness of their activities (investment policy, development activities).

The effectiveness of provision of public goods and services by small municipalities is influenced not only by the absence of externalities (agglomeration economies) but also by limited functional and professional capacities of the territorial self-government units (more voluntary

\footnotetext{
${ }^{5}$ This classification was used in the Czech Republic in the "budgetary allocation of taxes", where the revenue from shared taxes is redistributed to municipalities.

${ }^{6}$ Czech rural settlements had ceased to be purely agricultural since the end of the $19^{\text {th }}$ century, although agriculture had kept a decisive influence on their shape and on many features of the life of their inhabitants. This development affected the character of rural settlements, particularly those situated near large and medium-sized cities and industrial agglomerations. A relatively compact settlement structure, the specifics of industrialization processes in our country, gradual loss of job opportunities in the countryside and the specific situation at the local labour market have gradually led to a situation where villages and small towns have been changed to a considerable extent into mere "dormitories" for their inhabitants, who commute to larger centres for work and for services.

${ }^{7}$ Since the end of the 1990s, we can observe an outflow of the population from big cities to rural settlements in their immediate vicinity in order to obtain better quality housing and better living standard (suburbanization).
} 
than professional approach). This fact has been pointed out for a long time by our and by foreign experts (Stiglitz 1986, Widemannová 2001, Bradley - Lowe 1984, Maier - Tödtling 2006). In other countries, the issue of public finances is closely linked to a normative approach ${ }^{8}$, which does not take fully into account the spatial specifics. Taking into account this dimension requires the performance of empirical researches, which will make it possible to capture the impact of the size and location of municipalities on the effective provision and funding of public goods.

Efforts to strengthen the effectiveness and efficiency in delivering public goods and services has been associated with efforts to overcome the fragmentation of the settlement structure search of economic and administrative forms of integration. The possibility of merging or unification of municipalities to bigger administrative units has been discussed for a long time in the Czech Republic. However, these tendencies have been opposed by most representatives of small municipalities and of the cities as well ${ }^{9}$. Former concepts, which preferred the administrative method of reduction of the number of municipalities (the nodal settlement structure) and which endeavoured to increase the effectiveness of construction and operation of civic amenities and the availability of services, overestimated the advantages of concentration of the population in nodal municipalities (Slepička 1981). The results of such concentration process, which was designated to help increase the quality of life in small rural settlements, were ambiguous and had even some negative effects, particularly in certain regions (such as the Central Bohemia) ${ }^{10}$.

Similar problems have appeared in other countries, too, which led to a search for ways to achieve increased economic effectiveness in the provision of public services with the aim of keeping the inhabitants in the territory. One of the mechanisms that should help achieve the required savings is a pressure for a higher extent of merging of municipalities into larger units (such process occurred in the past e.g. in Germany, in the Netherlands and in Swiss); however, small municipalities often oppose these tendencies and are not interested in such unification.

This situation affects the quantity and range of goods and services provided by territorial selfgovernment units. The possibility to ensure basic services for the population is limited particularly in case of small municipalities, which is caused by a number of factors, such as the size of property and its management method, the volume of disposable funds designated for acquisition and reproduction of assets and the possibility of expanding the structure of sources designated for funding of the provided services ${ }^{11}$. This leads to a problem of how to make basic services available to the inhabitants of small settlements and how to ensure the functioning and further development of the municipality. This fact represents a difficult challenge facing the experts and the political representation - to find a balance between the extent of decentralization (connected also with the number of municipalities) and the effective funding of public services at the territorial self-government level.

\section{Importance microregional centers for small municipalities}

A characteristic feature of the Czech rural space is the daily commuting to work and services, which is reflected in many fields of life of its inhabitants. The separation between the place of work and residence (or the place of education) and also the place of consumption of services increases costs of the inhabitants of small settlements (transportation costs, loss of time). These negative phenomena are compensated by the natural catchment system, which makes it possible to keep the population in the territory. The traditionally large number of nodal centres in the Czech Republic (small and medium-sized cities), which provide the basic scope of services, contributes to the stability of the settlement structure and slows down the population outflow from rural areas. Commuting makes room for preserving the identification of citizens with their municipality and enhances the affiliation to the municipality and the closest microregion (catchment area).

\footnotetext{
${ }^{8}$ These are mostly classical works in the public finance area, which are based primarily on normative positivism, e.g. HOMPSON F. - GREEN M.T. (1998)

9 This fact was demonstrated repeatedly during the empiric research.

${ }^{10}$ Details regarding pros and cons of the nodal settlement structure see e.g. SLEPIČKA (1981)
} 
The fact that the relations between small municipalities and catchment centres have existed for a long time ${ }^{12}$ and affect the quality and intensity of the current spatial links was also proved during our empiric research. This fact has to be considered in the preparation of the future development concept of small municipalities and in any modification of administrative processes motivated by efforts to increase effectiveness of public administration and to enhance the development roles of territorial self-government units.

Our findings indicate that, although the restructuring of economy and foreign capital influx changed socio-economic links in the territory and transformed the economic structure of microregional centres, it did not cut historical links among municipalities but rather affected the intensity of flows. The public administration reform connected with the decentralization and transfer of state administration to microregional centres (municipalities with extended competencies) led to a revitalization or confirmation of their nodal role and to the intensification of their relations with small municipalities around them (Hampl 1996), Vaishar 2005, Čmejrek 2008, Matula - Kuba 2007).

The daily commuting of the population to these centres and the use of their public goods and of civic and technical amenities owned by the municipalities is one of the factors that could be reflected in the distribution of financial funds among municipalities. However, the existing knowledge is not sufficient to make a comprehensive characteristic of the significance of the catchment system for individual levels of services (provided by both private and public sector) which would lead to the formulation of exact conclusions that may be used for set-up of a stabilized funding system of municipalities (Peková 2008).

\section{Financing of small municipalities}

One of the factors that have a significant impact on financing of the territorial self-government in the Czech Republic is the high proportion of the revenue from taxes shared at the national level in the Czech Republic in current income of municipalities (Peková 2000).

In a situation where the tax revenue is distributed to municipalities in accordance with their size, big cities receive a much bigger per capita amount than small municipalities. On the one hand, we can refer to discrimination of the population of small municipalities; on the other hand, it has to be acknowledged that a substantial part of such re-distributed funds is generated in big cities. Small municipalities considered unfair the current distribution of shared taxes, which leads to a significantly higher amount of funding per capita of major cities. This is more than five times the amount allotted to citizens of the smallest municipalities. This argument, however, ignores the different administrative (Prague is a municipality and the region) and economic roles of these sites (providing public goods to citizens of other municipalities of the region, in the case of Prague and Brno, the city and citizens of other regions). Big cities argue that the volume of redistributed tax does not share these cities to GDP. The used model reflects the principle of solidarity between economically stronger and poorer municipalities (cities) ${ }^{13}$. This is the subject of current political debate. Given the specific structure of the settlement it is difficult to compare funding models in other countries.

Further existence and development of small municipalities is currently affected by a decline of available funds, caused by a growth of operating expenses and by structural problems of public budgets.

The existing situation is a topic of discussion initiated not only by small municipalities. Problems connected with this situation led to partial correction of this system. The amendment of the Act

\footnotetext{
12 The survey demonstrated persisting influence of the older administrative organization. Catchment centres are often municipalities that played a historical administrative role, i.e. settlements that had hosted district authorities or district courts dating back the administrative system created by the Austro-Hungarian Empire, which had been used until 1960. Another persistent feature can be seen in the original economic function of the municipality, i.e. the role of a town as a market for people from surrounding municipalities, etc.

13 Small municipalities stress high proportion of revenues on citizen in big cities which see also: PEKOVÁ (2004), PEKOVÁ (2000), TOTH (2008).
} 
on Budgetary Allocation of Taxes, which became effective on 1 January 2009, strives to improve the situation of small municipalities ${ }^{14}$.

The results of the empiric research confirmed the relation between the distribution of funds by budgetary allocation or by subsidies have highlighted the absence of consensus among representatives of municipalities. Their attitudes can be divided into two groups. The first group, represented mostly by small municipalities, preferred the abolishment of subsidies and the distribution of all funds through budgetary allocation of taxes. According to the representatives of small municipalities, drawing subsidies is connected with excessive administrative requirements, which block the limited staffing capacity of municipalities. Due to lack of own professional staff, such small municipalities are forced to use the services of independent consulting companies, which do not always provide good quality services. The purchase of these third-party services and lobbing is very financially demanding for smaller municipalities (details see the analysis).

The reason of current situation is the low capacity, essentially impossible to obtain foreign resources to finance the activities of the municipality. The size of the budget makes it effectively impossible to obtain credit from financial institutions, banks (income of future budget can serve as collateral for the loan). If the municipality does not have available assets which it would periodically provide additional revenues to the budget (rental property), or which would serve to obtain credit (liability), the municipality can realize virtually any investment plans ${ }^{15}$.

Due to insufficiency of funds to ensure availability of public goods, the municipalities also try to seek new forms of partnership with the private sector (Jetmar 2008).

A significant role is also played by the quantity of assets available to the municipalities. The ability of municipalities to provide public goods and services depends on their management, on the revitalization of their self-administrative role at the beginning of $1990 \mathrm{~s}$, on the professional level of the self-government authorities and on the skills of the management of municipalities (see Wokoun 2006). It turns out to solve problems arising from small amount of experience of representatives of municipalities with new possibilities of the management of municipal property that arose after 1989, with changes in the structure of assets owned by the territorial selfgovernment unit, e.g. with restitutions, the course and impact of privatization of property and with other factors that have an impact on effective management of assets for the purpose of provision of local public goods and services, of further development of the municipality ${ }^{16}$.

Different attitude to property ownership, the community demonstrated through our empirical investigation.

The attitude of municipalities and cities to the property, its possible future sale, the importance of management in the financing of long-term investment measures, it has developed two categories of villages and towns. The first category can include municipalities, which they owned the property for more cost item, they need to invest much, and where any income from rental property are below the required investment costs. Property has largely been sold to the private sector, respectively. property is still owned by municipalities remains, is regarded as an important tool for future negotiations with investors and will also be sold to a de facto (e.g. exchange of parcels of land, business development, utilization of new housing, industrial areas,

\footnotetext{
${ }^{14}$ The survey pointed to the persistence of different opinions on the existing model of funding of small municipalities, depending on the size of these municipalities. The discussion on re-distribution of funds between small and large municipalities has shown the necessity to take into account the range of services procured by each size category of municipalities and the lack of understanding of the role of settlements placed higher in the settlement hierarchy in the Czech Republic) (small municipalities - medium-sized cities- interregional centres and regional metropolises - the Capital City of Prague). On the other hand, representatives of individual size categories of municipalities were usually unable to specify precisely the way how to improve this set-up.

15 Obtaining credit is often the technical requirements for benefit and subsidies granted by the state or the EU, is used for financing of investments as a bridge between payment of invoices and the reimbursement of costs. Other sources, national or EU public grants very often requires to pay a minimum share of the investments costs. Although it is in relative terms only a fraction of the cost (often fine $7.5 \%, 15 \%$ ) of amount of project, the absolute amount may be a sum of millions of (typically in construction of water supply and sewerage networks, sewage plant), which becomes for small municipalities insurmountable barrier.

${ }^{16}$ The ownership of historical and cultural monuments represents a particularly excessive financial burden for small municipalities. Another problem may be the extent and capacity of social and technical infrastructure, which does not often correspond to current needs.
} 
supermarkets, etc.). Great emphasis is put on sale as well as community land for future construction and housing and attracting new residents in the municipality.

The second category consists of the village community, which is shedding assets. Assets in these communities considered to be an important tool for community development in terms of providing basic services and needs of local people (shops, schools, medical facilities, cultural activities, social housing, public space) and in terms of potential business communities and cities (e.g. campground operation, parking, lease municipal property for the catering and accommodation services, housing, etc.). Municipal property may be, in the opinion of the respondents also used for the development of local enterprises. Ownership of property is also considered an important tool to address local social and economic problems (e.g. the arrival of new residents).

What is concerning the funding of independent (self governing) competencies, our research has confirmed the expected high share of budget expenditures of the municipalities that is allocated to the school system and to technical and social infrastructure owned by the municipality ${ }^{17}$. These expenditures are closely linked with such parameters as the number of inhabitants and area of the municipality. In case of capital expenditures and investments into social infrastructure (mainly the school system), it is appropriate to take into account a supplementary parameter represented by the number or the share of children younger than 14 years of age. It was mainly the representatives of small municipalities who were inclined to the use of a larger range of parameters ${ }^{18}$. On the contrary, the research did not prove the relevance of such parameters as the number of seasonal inhabitants, the altitude above sear level or of the scope (length) of local communications has not been proved.

Another important factor that was referred to as a financial burden for municipalities is the ageing of buildings owned by small municipalities, including their housing fund, and the related increase of renewal and maintenance costs. Another problem indicated by the municipalities of all sizes is the care for public space (mainly public areas and greenery).

Just a small rural community, however, faced with the fundamental problems of securing funding and building of needed social and technical infrastructure. Although in recent years to bias the distribution of share tax income in favor of municipalities in the smallest size categories, it appears that even this partial modification will not substantially affect the status of these units.

Beside independent competencies, small municipalities are also charged with the execution of state administration tasks. This is represented by the so-called transferred competencies, which are delegated to a various extent to municipalities. By applying such combined model, the state expects to achieve some synergic links between the execution of independent and delegated competencies, which would lead to an overall reduction of local administration costs.

Small municipalities have usually basic competencies and the exercise of delegated competencies affects mainly the operation of the municipality as a public corporation and is not focused mainly on citizens. The second category of municipalities that exercise delegated competencies is represented by municipalities operating a civil register. The performance of these activities is deemed a burden mostly by representatives of small municipalities. Many small municipalities referred to staffing problems related to the performance of such entrusted tasks. A number of small municipalities are not managed by full time professionals; the magistrates in many of them do not perform their tasks on a full time basis and the municipalities face difficulties in finding highly skilled professionals to perform specialized

\footnotetext{
17 See mainly TOTH P. In: Závěrečná zpráva výzkumného úkolu Analýza financování výkonu státní správy a samosprávy územních samosprávných celků, která poskytne relevantní množství dat pro přípravu nového zákona o RUD.

${ }^{18}$ Some municipalities preferred a different model of redistribution of funding, which would also include other parameters beside the size (such as the number of permanent and seasonal inhabitants; the altitude above sea level; the number of housing units; the area of the municipality, etc.). Further ancillary criteria were proposed during the interviews, such as the number or share of inhabitants of post-productive age, the length of local roads, the scope of technical infrastructure (the number of connected inhabitants), the number of real properties (e.g. land register numbers, including recreation facilities), and the number of inhabitants employed in the territory of the municipality. Catchment municipalities proposed to take into account the administrative district of the municipality (according to the number of persons in such district).
} 
administrative tasks. The reasons include the partial coverage of costs incurred in connection with the exercise of delegated competencies.

In our analysis of funding of delegated competencies, we monitored mainly the actual costs incurred in connection with the exercise of delegated competencies and compared them with the income generated by these activities. The calculation of income and expenses was based on the data from the ARIS system operated by the Ministry of Finance ${ }^{19}$. Selected expenditures were weighted by the number of working hours of officials exercising delegated competencies. A significant finding in this respect is the difficult quantification of the share of financial and human resources in the exercise of independent and delegated competencies.

A quantitative analysis of data from the years 2005-2007, the questionnaire survey and managed interviews have confirmed the following facts. There is a significant difference in the extent of coverage of expenses connected with the exercise of delegated competencies by ascribed income, depending on the highest administrative role played by the municipality. Municipalities that have only basic functions (small rural municipalities) have their expenditure covered only to several tens of percent (the maximum average value $-20.70 \%$ - was achieved in 2007).

The coverage of expenses by income increased in the years 2005 to 2007 in all categories of municipalities. The biggest increase was witnesses by municipalities with authorized municipal authority - from $57.9 \%$ to $68.5 \%$ - and with the basic function - from $14.1 \%$ to $20.7 \%$; at the same time, the difference between the extent of coverage in individual categories of municipalities did not change significantly between the years 2005 and 2007.

\begin{tabular}{|l|c|c|c|c|c|}
\hline Years & \multicolumn{3}{|c|}{ Small municipalities } & & \\
\cline { 2 - 6 } & $\begin{array}{c}\text { Municipalities } \\
\text { with basic } \\
\text { functions }\end{array}$ & $\begin{array}{c}\text { Municipalities } \\
\text { with a civil } \\
\text { register }\end{array}$ & $\begin{array}{c}\text { Municipalities } \\
\text { with a } \\
\text { building office }\end{array}$ & $\begin{array}{c}\text { Municipalities } \\
\text { with authorized } \\
\text { municipal } \\
\text { authority }\end{array}$ & $\begin{array}{c}\text { Municipalities } \\
\text { with extended } \\
\text { competencies }\end{array}$ \\
\hline 2005 & 14.1 & 38.2 & 45.1 & 57.9 & 103.9 \\
\hline 2006 & 13.2 & 38.9 & 47.4 & 59.0 & 98.4 \\
\hline 2007 & 20.7 & 40.7 & 50.5 & 68.5 & 105.1 \\
\hline
\end{tabular}

Tab 2. Extent of coverage by administrative roles of municipalities in individual years in \%

Source: Own calculations made by JETMAR M. based on data provided by the Ministry of Finance and Ministry of the Interior of the Czech Republic and by municipalities

The significant difference between the amount of coverage of expenditure incurred in relation to the exercise of delegated competences (depending on the highest achieved administrative role of the municipality, with a significant progression in favour of bigger municipalities) led to a proposal of change of funding of delegated competencies in favour of smaller municipalities (municipalities with basic competencies and municipalities with civil register).The fact that municipalities must cover a part of the exercise of delegated competencies from other funds (i.e. those designated for the exercise of independent competencies) has been designated by the municipalities as negative for a long time. Municipalities often resolve this situation by a reduction of the volume of funds designated for investments or for property maintenance. In unique cases, this was resolved to the detriment of financial remuneration of officials. The survey also referred to further negative phenomena, such as wage discrimination of officials exercising delegated competencies.

\footnotetext{
${ }^{19}$ In accordance with the applied method, capital expenditures relating to the acquisition and modernization of office buildings or office rentals were not taken into account in the calculation of expenditures related to the exercise of delegated competences. The inclusion of these expenditures would lead, of course, to a reduction of the extent of coverage.
} 


\section{Conclusion}

Obtained findings confirm the importance of a range of factors that affect the development potential of small municipalities - geographic, economic, administrative, financial and also socio-cultural. Financial and economic aspects are in the literature to date reflect little, so we gave them more attention. It has been proved that only some of them can be clearly captured by research method and can be reflected in quantitative characteristics that can become a basis for the funding system of municipalities or distribution of revenue from shared taxes.

Also results of our empiric research have confirmed the effect of long-term parameters characterizing the status and functioning of small municipalities (position in settlement hierarchy, functional role, peripherality, etc) and the limitation of availability of sources. In many areas, these results have contributed to an expansion and deepening of knowledge, particularly about the impact of administrative and economic reforms, regulation of funding of municipalities, about current problems and possibilities of the development of small municipalities in the Czech Republic.

The project results highlighted significant aspects of functioning of municipalities during the provision of public goods and services; in case of small municipalities, they highlighted their limited ability to ensure further development of the municipality (or to preserve its attractiveness for its inhabitants) under the current rules for distribution of public funds.

Partly usable factors, for instance for the construction of budgetary allocation of taxes, include, inter alia, the characteristics of the settlement structure in the Czech Republic, the position of small municipalities in the settlement hierarchy and the effects of the catchment system. For the purpose of construction of the model of distribution of funds among municipalities, it has proved as necessary to work with a very narrow circle of quantifiable parameters, which have a substantial effect on the amount of the municipality's expenditures.

Set-up of an effective and stabilized funding system of small municipalities should be systematically based on the determination of the scope of basic activities to be carried on by territorial self-government unit and their ability to effectively manage the provision of goods and services. With regards to funding of these activities, it is necessary to set up measurable parameters that will direct the allocation of funds available to the municipality and will make it possible to monitor the effectiveness of spending. The application of such parameters will allow mutual comparison and such parameters may also become a basis for standardization (details see in Peková - Pilný - Jetmar 2008).

This system of funding of rural municipalities could enable small municipalities to adopt longterm strategic decisions on their development priorities and to establish the appropriate framework of funding public goods and services.

The study of this issue has revealed the existence of a number of partial problems, which should be resolved through subsequent specialized research. Such resolution would contribute to an optimum set-up of competencies (both independent and delegated) in ensuring the offer and availability of public goods. The research has shown the necessity to establish closer cooperation of small municipalities with settlements at higher hierarchy level, which offer a broader scope of public goods and represent centres of job offer, educational and cultural activities and abroad range of commercial services for the rural population. The distribution of tax revenue should take into account the relation between small rural municipalities and catchment centres (i.e. the mission of catchment municipalities in increasing attractiveness of the countryside for the local population) and also the balancing of the relation between funding of rural and urban settlements.

Another problem seems real low availability of grant resources for the small community of public budgets. The current system does not facilitate financing of small communities to obtain investment funds for development activities. Small communities are also forced to seek nontraditional forms of financing and greater use of the internal potential, including the direct involvement of citizens and local businesses. 
[1] ANDRLE A (2003). Fakta a úvahy o vývoji osídlení v ČR. Územní plánování a urbanismus 6(6), 16-35.

[2] ANDRLE A (1998). Minulost, přitomnost a budoucnost venkova. Obec a finance 3(1).

[3] ANDRLE A., HLADíK J. et al. (2002). Průzkum venkovského osídlení a bydlení. Part I. , Part II. Veřejná správa no. 47,48

[4] BAREŠ P. (2007). Realizace sociálních služeb na úrovni obce s pověřeným obecním úradem. In Grospič, J., Louda T. \& Vostrá L. (Eds.), Územní samospráva v České republice a Evropě. Plzeň: Aleš Čeněk.

[5] BAŠE M., CÍLEK, V. (2006). Krajina domova v době rozpadu města a přeměny venkova. Veřejná správa, No.19, p. 2-12.

[6] BERAN V., DLASK, P. (2005). Management udržitelného rozvoje regionů, sídel a obcí. Praha: Academia.

[7] BLAŽEK J. (2003) System of Czech Local Governament Financing as a Framework for Local Development. 12 Years of Trial and Error Approach. Acta Universitatit Carolinae Geographica, 37(2), 157-174.

[8] BLAŽEK B. (2004). Venkovy: anamnéza, diagnóza, terapie. Brno: ERA.

[9] BRADLEY, T. \& LOWE, P. (eds, 1984). Locality and Rurality: Economy and Society in Rural Regions, Norwich: Geo Books.

[10] CAFFYN A., DAHLSTROM M. (2005). Urban-Rural Interdependencies: Joining up Policy in Practice. Regional Studies, 39(3), 283-296.

[11] Collection of reports from the international conference "Countryside Is Our World" 2006). Praha: Czech University of Agriculture.

[12] COURTNEY P., MAYFIELD L., TRANTER R., JONES P., \& ERRINGTON A (2007). Small towns as 'sub-poles' in English rural development: Investigating rural-urban linkages using sub-regional social accounting matrix. Geoforum 38(6), 1219-1232.

[13] Český venkov na přelomu tisíciletí (1997). Praha: Czech University of Life Sciences.

[14] ČERMÁK Z. (2005). Migrace a suburbanizační procesy v České republice. Demografie, 47(3), 169-176.

[15] ČMEJREK J. (2008). Obce a regiony jako politický prostor. Praha: Alfa.

[16] Distribution and Concentration of the Population of the Czech Republic. Size Structure of Municipalities (2004). Praha: Czech Statistical Office.

[17] DOMENACH C. (1978). Administration et Urbanisation en France, Grenoble: UPMF France.

[18] FUJITA M., KRUGMAN P. \& Venables, A.J. (2001). The Spatial Economy: Cities, Regions, and International Trade. Cambridge: Massachusetts Institute of Technology.

[19] GREGA L., HRDINOVÁ B., \& PAVLÍČKOVÁ H. (2008). Entrepreneurial Activities Support and Regional Sustainable Development Indicators. In: ICABR 2008, ACCRA, GHANA (pp. 336-350) Brno: Mendel University.

[20] GREMLICA T (2001). Hrozba jménem Urban Sprawl: Chaotický růst městských aglomerací ohrožuje i Českou republiku. Veřejná správa no. 26, p.1-3.

[21] GROSPIČ J. (2007). K některým otázkám vývoje územní veřejné správy. In Grospič, J., Louda T. \& Vostrá L. (Eds.), Územní samospráva v České republice a Evropě. Plzeň: Aleš Čeněk.

[22] HAMPL M. (1996). Hierarchie systému osídlení a administrativní členění České republiky. In: Geografie, 101(3), 201-210. 
[23] HAMPL, M. (1999). Dlouhodobé trendy ve vývoji osídlení. In: Hampl M. et al., Geografie sociální transformace $v$ České republice. Praha: Charles University.

[24] HAMPL M. (2005). Geografická organizace společnosti v České republice: transformační procesy a jejich obecný kontext. Praha: Charles University.

[25] HAMPL, M., GARDAVSKÝ V., \& KÜHNL K. (1987). Regionální struktura a vývoj systému osídlení ČSR. Praha: Universita Karlova.

[26] HAMPL M. \& MÜLLER J. (1998). Jsou obce v České republice př́liš malé? Geografie, 103(1), 1-12.

[27] HRABÁNKOVÁ, M. \& TRNKOVÁ V. (1996). Hodnocení území z pozice agrární regionální politiky a rozvoje venkova, Institute of Agricultural Economy and Information, Prague, Research study no. 3581.

[28] HURON, D. \& SPINDLER, J. (1998). Le management public local, Paris: L.G.D.J.

[29] JETMAR, M. (2006). Financování potřeb obcí prostřednictvím spolupráce veřejného a soukromého sektoru. In LOUDA, Tomáš, GROSPIČ, Jiří, VOSTRÁ, Lenka (Eds.) Modernizace veřejné správy v Evropě a České republice (pp. 265-291). Plzeň: Aleš Čeněk.

[30] JETMAR M. (2005). Financování potřeb obcí prostřednictvím spolupráce veřejného a soukromého sektoru - Clustery a regionální rozvoj. In: TOTH, P. et al. Financování obcí, sociálně ekonomický rozvoj systému (pp. 159-193). Praha: Oeconomica.

[31] JETMAR, M. (2004). Místní správa a otázka partnerství s dưrazem na územní rozvoj. Acta Oeconomica Pragensia, 12(4), 237-248.

[32] JETMAR M. (2008). Spolupráce a partnerství veřejného a soukromého sektoru. In: PEKOVÁ J., PILNÝ J, \& JETMAR, M. Veřejná správa a finance veřejného sektoru. $3^{\text {rd }}$ Praha: ASPI.

[33] KADEŘÁBKOVÁ, J. (2006). Komunikační strategie územní samosprávy v regionálním rozvoji. In Modernizace veřejné správy v Evropě a České republice. Plzeň: Aleš Čeněk.

[34] KADEŘÁBKOVÁ J. (2008). Sídelní struktura. In Úvod do regionálních věd a veřejné správy. PIzeň: Aleš Čeněk.

[35] KADEŘÁBKOVÁ, J. (2002). The role of the local and regional Communities in the Realization of the Development Projects. In EU Enlargement in a Changing World. Ljubljana.

[36] KADEŘÁBKOVÁ, J. (2008). Urbanizace, suburbanizace, desurbanizace. In Úvod do regionálních věd a veřejné správy. Plzeň: Aleš Čeněk.

[37] MAIER, G. \& TÖDTLING, F. (2006). Regional-und Stadtökonomik 1: Standorttheorie und Raumstruktur, Wien New York: Springer.

[38] MAIER, K. (2000). The Role of Strategic Planning in the Development of Czech Towns and Regions. Planning Practice and Research 15(3), 247-255.

[39] MAIER, K. \& ČTYROKÝ, J. (2000). Ekonomika územního rozvoje, Praha: Grada.

[40] MAJEROVÁ, V. et al. (2005). Český venkov 2005 - Rozvoj venkovské společnosti, Praha: Czech University of Life Sciences.

[41] MAJEROVÁ, V. et al. (2005) Český venkov 2004 - Život mladých a starých lidí. Praha: Czech University of Agriculture.

[42] MATES, P., WOKOUN, R. et al. (2001). Malá encyklopedie regionalistiky a veřejné správy. Praha: Prospektrum.

[43] MATULA, M. \& KUBA, J. (2007). Základní problémy reformy veřejné správy a stav jejich řešení. In MATES, P., Reforma veřejné správy (pp. 301 - 319). Praha: ASPI.

[44] MATOUŠEK, V. (1991). Dosavadní vývoj a tendence rozvoje sídel v ČSSR. Demografie 4. 
[45] MOŽNÝ, I. (2002). Česká společnost. Nejdůležitější fakta o kvalitě našeho života. Praha: Portál.

[46] MUSIL, J. et al. (1985). Lidé a sídliště. Praha: Svoboda.

[47] MUSIL, J. (1988). Nové pohledy na regeneraci našich měst a osídlení. Územní plánování a urbanismus, 15( 2), 67-72.

[48] Musil, J., \& Müller, J. (2008). Vnitřní periferie v České republice jako mechanismus sociální exkluze. Sociologický časopis/Czech Sociological Review, 44(2), 321-348.

[49] OUŘEDNíČEK. M. (2002). Suburbanizace v kontextu urbanizačního procesu. In Sýkora, L. (Ed.), Suburbanizace a její sociální, ekonomické a ekologické důsledky (p. 39-54). Praha: Ústav pro ekopolitiku.

[50] Ouředníček, M., ed. (2006): Sociální geografie Pražského městského regionu. Praha: Univerzita Karlova.

[51] PEKOVÁ, J. (2004). Efektivnost zabezpečování lokálních a regionálních veřejných statků jako jedna z cest řešení fiskální nedostatečnosti územní samosprávy. In Collection of scientific studies. České Budějovice: University of South Bohemia.

[52] PEKOVÁ. J. (2007). Finanční aspekty reformy územní samosprávy v ČR. In MATES, P., Reforma veřejné správy (pp. 301-319). Praha: ASPI.

[53] PEKOVÁ, J. (2001). Finanční aspekty vztahů: stát - ministerstva - obce a kraje v ČR. Správní právo, 34(1), 13-33.

[54] PEKOVÁ, J. (2008). Finanční systém územní samosprávy, rozpočet a mimorozpočtové fondy. In Úvod do regionálních věd a veřejné správy (pp. 232-283). Plzeň: Aleš Čeněk.

[55] PEKOVÁ, J. (2000). Místní veřejná správa a místní finance v ČR a srovnání s EU. In REKTOŘÍK, J., ŠELEŠOVSKÝ, J. et al. Evropská Unie, obce a města. (pp. 33-38). Brno: Masaryk University.

[56] PEKOVÁ, J. (2000). Změny rozpočtového určení daní v kontextu fiskální decentralizace devadesátých let v České republice. Obec \& finance, 4(4), 20-21.

[57] PEKOVÁ, J., PILNÝ, J. \& JETMAR, M. (2008). Veřejná správa a finance veřejného sektoru. $3^{\text {rd }}$ edition. Praha: ASPI.

[58] PERLíN, R. (2008). Stanovisko k vymezení venkovského prostoru. [research report]. Praha: Czech Statistical Office.

[59] PERLíN, R. (2002). Nízkopodlažní výstavba v územních plánech obcí v zázemí Prahy. In Sýkora, L. (Ed.), Suburbanizace a její sociální, ekonomické a ekologické důsledky (pp. 141 156). Praha: Institute for Environmental Policy.

[60] PERLíN, R. (1998). Typologie českého venkova. Zemědělská ekonomika 44(8), 349-358.

[61] PERLíN, R., KULDOVÁ, P. (2008): Typology of rural areas. In Majerová, V. (Ed.), Countryside-our world (pp. 487-509). Praha: Czech University of Agriculture.

[62] PLOEG, J.D. van der (2003). Mobilising local actors: Stakeholder activities and networking in rural areas. In European Committee, DG VI (Ed.), Planting seeds for rural future. Rural policy perspectives for a wider Europe (pp. 137-144). Brussel: European Commission.

[63] PLOEG, J.D. van der (2006). Rural development: A Challenging Assignment of the Social Science. In Majerová, V. (Ed.) Countryside-our world (pp. 30-41). Praha: Czech University of Agriculture in Prague).

[64] RYŠAVÝ, Z. et al. (1990). Problémy rozvoje venkovského osídlení, malých a středně velkých měst Československa a jejich demografické struktury. Praha: Research Institute of Building and Architecture.

[65] SATTERTHWAITE, D. \& TACOLI, C. (2003). The urban part of urban development: the role of small and intermediate urban centres in rural and regional development and poverty reduction. London: International Institute for Environment and Development. 
[66] Small Lexicon of Municipalities in the Czech Republic (2004). Praha: Czech Statistical Office.

[67] SLEPIČKA, A. (1981). Venkov a/nebo město, Lidé/sídla/krajina, Praha: Svoboda.

[68] SIMON, H.A., THOMPSON, V.A. \& SMITHBURG, D. W. (1991). Public Administration. New Brunswick and London: Transaction Publisher.

[69] SÝKORA, J. (1998). Venkovský prostor, Vol. 2, Praha: Czech Technical University.

[70] STIGLITZ, J.E. (1986). Economics of the Public Sector. New York: W.W.Norton.

[71] ŠTENCLOVÁ, Š. (2005). Obnova venkovského prostoru, Praha: Czech University of Agriculture.

[72] TRNKOVÁ, V. (2005). Zemědělství jako součást venkova a krajiny. In Majerová V. et al.: Český venkov 2005-Rozvoj venkovské společnosti. Praha: Czech University of Agriculture.

[73] TOUŠEK, V., KUNC, J., VYSTOUPIL, J. et al. (2008). Ekonomická a sociální geografie. PIzeň: Aleš Čeněk.

[74] TOTH, P. (2007). Problémové okruhy v rozpočtování územní samosprávy v ČR. In GROSPIČ, J., LOUDA, T. \& VOSTRÁ, L. (Eds.), Územní samospráva v České republice a Evropě. Plzeň: Aleš Čeněk.

[75] TOTH, P. (2008). Vývoj rozpočtového určení daní v ČR. In Teoretické a praktické aspekty veřejných financí [CD-ROM, p. 42]. Praha: Oeconomica.

[76] THOMPSON, F. \& GREEN, M.T. (1998). Handbook of Public Finance. New York - Basel Hong Kong: Marcel Dekker.

[77] VALLETOUX, P., RICHARD, P. \& NARMON F. (1997). Local Finance in the Fifteen Countries of the European Union. Brussels, Paris: Dexia.

[78] VAISHAR, A. (2004). Small towns: an important part of the Moravian settlement system. In Pak, M., Rebernik, D. (Eds.), Cities in transition (pp. 309-318). Ljubljana: Univerza v Ljubljani.

[79] VAISHAR, A. (2005): Small Towns as Centres of Rural Microregions. In Komornicki, T. \& Czapiewski, T. (Eds.): Central and Eastern Europe: Changing Spatial Patterns of Human Activity (pp. 53-62). Warszawa: Institute of Geography and Spatial Organization PAN.

[80] VYSTOUPIL, J. \& ŠíP, J. (2005). Metodika analýzy hodnocení území venkovského prostoru $v$ intencích trvale udržitelného rozvoje cestovního ruchu jako základní nástroj nové rajonizace CR. In Reviewed Collection + CD ROM of papers presented at the $10^{\text {th }}$ International Conference on Tourism, Regional Development and School System, Permanently Sustainable Development and Tourism (p. 147-153). Tábor: University of South Bohemia.

[81] VYSTOUPIL, P. (2006). Venkovský cestovní ruch v České republice. In Perspektivy českého venkova (pp. 34-39). Praha: Czech University of Life Sciences.

[82] WIDEMANNOVÁ, M. (2001). Vztah mezi velikostí obcí a regionů a efektivností a hospodárností jejich činnosti. Veřejná správa Nr. 15, p. 12, 21, 22.

[83] WOKOUN, R. (2007). Regionální rozvoj a jeho management v České republice. Praha: University of Economics.

[84] WOKOUN, R., KOUŘILOVÁ, J., COGAN, R., GROSPIČ, J., HEŘMANOVÁ, E., JETMAR, M., KADEŘ́ÁBKOVÁ J., MACHÁČEK J., MATES P., MATULA M., WIDEMANNOVÁ, M. et al. (2007). Management regionálního rozvoje na úrovni krajů a obcí s rozšířenou působností. In WOKOUN, R. et al., Regionální rozvoj a jeho management v České republice (pp. 155244). Praha: Oeconomica.

[85] WOKOUN, R. \& MATES, P. (Eds.), Management regionální politiky a reforma veřejné správy. Praha: Linde. 
[86] ZSILINCSAR, W. (2003). Future Perspectives for Small Urban Centres in Austria. Geografický časopis 55(4), 309-324.

[87] ŽÁRSKÁ, E., KOZOVSKÝ, D. (2008). Teoretické a praktické aspekty fiškálnej decentralizácie. Bratislava: Ekonóm. 